with Dr. F. H. Burstall, gives an interesting account of recent high-pressure work which has been carried out at the Chemical Laboratory, Teddington, on the dehydrogenation of pyridine with anhydrous metallic chlorides. One of the products of the reaction, $2: 2^{\prime}$-dipyridyl, yiclds particularly important coordination compounds (NATURE, 128, 31, July 4, 1931).

THE two other contributions from Great Britain are by Prof. M. W. Travers and Prof. F. G. Donnan, the former discussing the pyrolytic condensation and decomposition of ethane in the presence of hydrogen, whilst the latter presents a short but stimulating note on the thermodynamic functions of radiation. Students of the chemistry of the polysaccharides will welcome a valuable resume of recent investigations in this field from the pen of Prof. H. Pringsheim. Another paper of great interest by Prof. Franz Fischer summarises the valuable work on the utilisation of coal gas which he has carried out during the past few years. As would be anticipated by those who have followed the trend of chemical research in India, the majority of the papers by Sir Prafulla's former students are on physico-chemical themes and are of interest mainly to the specialist. Prof. M. N. Saha has, however, written a remarkably able review entitled "Spectroscopy in the Service of the Chemist". The contributions to this commemoration volume reach a high standard and augur well for the future of the schools of chemistry in India of which Sir Prafulla may with justice regard himself as the founder.

\section{Mr. Pierre Chevenard}

THE "Societe d'Encouragement pour l'Industrie Nationale" awards annually a special medal with the effigy of an eminent person in science or arts to a French or foreign author whose work has had the most effect on the progress of French industry. The medal for 1932 bears the effigy of Prony and has been awarded by the Committee of the Society dealing with mechanical arts to $M$. Pierre Chevenard, a mining engineer of the Mining School at Saint Etienne. Born in 1888, M. Chevenard has, since 1910, worked in the research laboratory at Imphy of the metallurgical works of Commentry, Fourchambault et Decazeville. One of his most important papers deals with an experimental research on iron, nickel and chromium alloys, but he is especially known for elaborating devices for the examination of very small quantities of alloys. With small samples a homogeneous temperature is secured throughout the piece, this being important for quick and reliable measurements, and M. Chevenard was able to examine the physical properties of alloys over a wide range of temperature. His differential dilatometer, galvanopyrometer, and apparatus for the examination of the mechanical properties of alloys, are widely used all over the world. Besides purely scientific research, M. Chevenard has contributed a great deal to the production of special alloys at Imphy, such as M. Ch. Guillaume's invar, elinvar and the A.T.V. ferronickel alloy.

\section{Concealing Coloration of the Tapir}

THE birth at the Gardens of the Zoological Society of London, last week, of a Brazilian tapir is worth recording, since it will afford visitors to the Gardens an opportunity of examining one of the most striking types of 'protective', or 'concealing coloration' in young mammals to be found anywhere. It takes the form of numerous longitudinal white stripes on a black background. The stripes tend to break up into short bars and spots on the flanks, whilo the legs are obliquely striped. The face is spotted. This coloration is the more interesting because the young of the Malayan tapir is coloured after a closely similar fashion; while the adults of the two species are as unlike as could well be. In the young Malayan species the spots on the face are more numerous and distinct, while the stripes down the sides are rather more sharply defined and less broken up on the lower flanks. As the animal approaches maturity these markings fade out in a very curious way. As the great white area of the body behind the withers gradually shows up, the stripes fade out; but they persist far longer on the black fore-quarters and the face. The strange coloration of the adult Malayan tapir affords another striking example of 'concealing coloration', since when asleep in dry boulder-strewn water courses these animals look themselves like boulders, the white area forming the summit while the black fore-quarters and legs simulate the deep shadows cast by such boulders in the intense sunlight.

\section{Theory in Modern Physics}

The leading idea of Prof. A. Einstein's Herbert Spencer lecture, entitled, "The Method of Theoretical Physics", delivered at Oxford on June 10 was the relation between experience and reason in the domain of physics. The Greeks, ho said, perfected a logical system in which, considered as such, no flaw could be found. But it was a closed system; and its concepts and laws, though for long believed to be derivable from the data of experience, were entirely a creation in the mind of the theorist. The practical success of theory in the hands of Newton obscured during the eighteenth and nineteenth centuries the want of correspondence, now evident, of pure theory with the results of experience. But though the view that prevailed for so long must be discarded, Prof. Einstein believes it to be possible for the theorist to construct a system that will be a true model of reality. Experience cannot give the answer to the problem of Nature, but it can suggest the methods which will enable the theorist to arrive at a solution.

\section{Inadequacy of Economic Sanctions}

IN a recent issue of the New Commonwealth-a journal devoted to the promotion of international law and order-Dr. J. J. van der Leeuw discusses the inadequacy of economic sanctions. The greater the measure of disarmament, he writes, the greater the need for sanctions. Complete disarmament, though this is the only safe basis for a lasting peace, is unthinkable without safeguards against aggression by an improvised attacking force. Such safeguards, 